Informe especial

\title{
Desarrollo de agentes inmunizantes contra el dengue
}

\author{
Francisco J. López Antuñano ${ }^{1}$ y Javier Mota ${ }^{2}$
}

RESUMEN El complejo de los cuatro flavivirus del dengue es transmitido principalmente por el mosquito Aedes aegypti. Se han atribuido epidemias a la actividad de A. albopictus, A. polynesiensis y a varias especies del complejo A. scutellaris. Los factores de riesgo que determinan la probabilidad de enfermar o morir por dengue están relacionados tanto con el huésped (características genéticas, estado inmunitario, forma de vida y condiciones de salud, saneamiento básico de la vivienda y abastecimiento de agua potable) como con el virus (variabilidad genética de cepas entre y dentro de los serotipos, diferente capacidad patógena y distribución geográfica). A pesar de la falta de conocimiento sobre la inmunobiopatología del dengue, se han hecho importantes avances para conseguir una respuesta inmunitaria protectora con virus atenuados $y$ con antígenos obtenidos por medio de tecnologías recombinantes. Desde los años 40, se ha intentado desarrollar vacunas contra el dengue. La inmunidad que se adquiere por infección natural es específica para cada serotipo y se han documentado infecciones por tres serotipos diferentes en la misma persona, por lo que probablemente sea necesaria una vacuna tetravalente. En voluntarios se han probado vacunas contra los cuatro serotipos que han sido inmunógenas y seguras. Aunque las vacunas con virus atenuados son prometedoras, son necesarios nuevos estudios sobre su eficacia y seguridad. Actualmente están en curso estudios para producir vacunas contra el virus del dengue mediante tecnologías de ADN recombinante y otras técnicas de biología molecular, utilizando como antígenos proteínas estructurales (principalmente la glicoproteína E) y no estructurales. Con el mismo propósito se han usado varios vectores de expresión, como Escherichia coli, baculovirus, virus de la vacuna y virus de la fiebre amarilla. Lamentablemente, no se han obtenido resultados satisfactorios en el hombre. La necesidad de desarrollar vacunas eficaces contra el dengue tiene especial importancia si se toma en cuenta la magnitud del problema de la transmisión de los cuatro serotipos en el mundo. La inmunización efectiva contra el dengue contribuirá a su prevención y la relación costo-beneficio será positiva. El hecho de que el dengue endémico afecte a niños de corta edad hace necesaria su inmunización, aprovechando la oportunidad que ofrece el Programa Ampliado de Inmunización.

El dengue, que constituye un grave problema de salud pública en regiones tropicales y subtropicales, es una enfer-

\footnotetext{
1 Instituto Nacional de Salud Pública, Cuernavaca, Morelos, México. Toda la correspondencia debe ser enviada a: Francisco J. López Antuñano. Dirección postal: Avenida Universidad No. 655, Colonia Santa María Ahuacatitlán, 62508 Cuernavaca, Morelos, México. Correo electrónico: alantu@insp3.insp.mx

2 Instituto Nacional de Salud Pública, Cuernavaca, Morelos, México.
}

medad infecciosa aguda caracterizada por fiebre bifásica, cefalea, dolor en varias partes del cuerpo, postración, erupción cutánea, linfadenopatía y leucopenia. En las formas graves o complicadas los pacientes presentan una enfermedad febril caracterizada por alteraciones de la hemostasis e incremento de la permeabilidad vascular que, en algunas ocasiones, puede causar choque hipovolémico. Existen cua- tro serotipos de virus del dengue (DEN-1, DEN-2, DEN-3, y DEN-4), con numerosas cepas en todo el mundo. En 1998 el dengue era la enfermedad tropical más importante después de la malaria, con un número estimado de 100 millones de casos de dengue "clásico", 500000 de dengue hemorrágico (DH) y 25000 muertes por año $(1,2)$. A pesar de que las estrategias tradicionales de control del principal vector, 
Aedes aegypti, han mostrado gran eficacia, la organización de programas permanentes sustentados por la participación social para el manejo integrado del ambiente y el control del vector sigue siendo un objetivo importante (3). El desarrollo de vacunas y su empleo combinado con el control del vector de la enfermedad ofrece la posibilidad de prevenir o eliminar las epidemias en el ser humano (4). Además de las consideraciones inmunológicas para obtener la mayor eficacia y seguridad de las vacunas en los seres humanos, para la inmunización universal hay que tener en cuenta la factibilidad industrial, el propósito de las nuevas vacunas y el tiempo deseado de protección, a fin de simplificar los esquemas de inmunización. Se ha otorgado prioridad a la búsqueda de formulaciones de inmunógenos que sean compatibles con estos objetivos y se esperan cambios significativos a corto plazo en los programas de prevención (5).

En la actualidad se dispone de diversos enfoques metodológicos para producir vacunas contra virus: virus vivos atenuados, virus completos inactivados o subunidades víricas, vectores víricos recombinantes, péptidos, proteínas recombinantes y vacunas de ADN. Sin embargo, la eficacia de una vacuna depende en gran medida de la inmunobiología de la infección vírica en cuestión y de la tecnología disponible para el tipo de antígeno seleccionado. En este artículo se presentan los resultados de estrategias recientes, con el objetivo de que el lector en general, y el salubrista en particular, dispongan de información actualizada para juzgar el grado de desarrollo de las vacunas contra el dengue.

\section{LA RESPUESTA INMUNITARIA Y LAS ESTRATEGIAS PARA DESARROLLAR VACUNAS CONTRA EL DENGUE}

La búsqueda de solución a los problemas relacionados con las causas y la patogenia del $\mathrm{DH}$ se ha analizado desde el punto de vista epidemiológico desde los años 70. Las hipótesis incluyen la mutación o selección del virus, el efecto sinérgico de infecciones dobles con dos serotipos del virus del dengue o con el virus del dengue y otro agente infeccioso aún no identificado, o infecciones dobles por virus del dengue que ocasionen una recombinación o mezcla fenotípica de virus que origine cepas más virulentas. La sensibilización del huésped humano por infecciones previas puede ser también un factor determinante del síndrome de choque o del DH (6), como se demostró en Cuba, en 1997, durante la segunda epidemia de dengue por el virus DEN-2, genotipo Jamaica. La infección secundaria fue uno de los principales factores de riesgo de $\mathrm{DH}$ y se observó la posibilidad de contraer $\mathrm{DH}$ tras una infección secundaria 16 a 20 años después de la primoinfección (7). La transmisión de la enfermedad y la frecuencia de las epidemias causadas por múltiples serotipos en Asia han aumentado la circulación de los virus hacia otras regiones, dando por resultado un aumento drástico del dengue epidémico, la hiperendemicidad (cocirculación de varios serotipos) y la emergencia del DH en las islas del Pacífico, del Caribe y en los países de Centroamérica y América del Sur. En menos de 30 años, tanto los países tropicales de América como las islas del Pacífico pasaron de no tener dengue a tener un problema importante de dengue/DH en 1998 (8). La eficacia de una vacuna contra el virus del dengue depende de que la intensidad del estímulo permita obtener un alto nivel de anticuerpos neutralizantes (9), consiga proteger durante largos períodos de tiempo a las personas vacunadas y no represente un riesgo para la salud, ya sea por la producción de viremia o por la inducción de anticuerpos no neutralizantes que potencien infecciones subsecuentes por virus heterólogos (10).

La respuesta inmunitaria celular desempeña un papel crítico en las infecciones víricas en general, y en el dengue en particular, ya que los linfocitos T (LT) son activados por la infección in vivo, primero los LT CD4 ${ }^{+}$, durante el período de viremia, y después los LT CD8 ${ }^{+}$. La activación de los LT in vivo puede contribuir a controlar la fase aguda de la infección (11). Para la producción de vacunas eficaces y seguras contra los virus del dengue es requisito sine qua non conocer bien la respuesta inmunitaria in vivo en la fase aguda de la infección.

La complicación más grave de la infección, el DH, parece ser mediada inmunológicamente y podría ser desencadenada por los LT citotóxicos específicos para los virus del dengue, junto con las características genéticas del húesped humano (12). También es probable que esos LT citotóxicos específicos sean importantes para la recuperación de la infección. Es indispensable disponer de mayor información sobre la respuesta de los LT citotóxicos con memoria para determinar la diversidad de la respuesta a los virus del dengue y para identificar las proteínas inmunodominantes. Para eso, Mathew et al. (13) usaron leucocitos mononucleares de sangre periférica (LMSP) de voluntarios sanos que habían recibido vacunas monovalentes con virus vivos atenuados de los cuatro serotipos. Los donantes mostraron proliferación de LT específicos para el virus del dengue y para otros flavivirus probados. Se generaron LT citotóxicos a partir de los LMSP estimulados de todos los donantes y en la mayoría de los casos estudiados se demostró actividad de los LT citotóxicos $\mathrm{CD}^{+}$específica frente al virus del dengue. Aunque no de manera uniforme, los LT citotóxicos $\mathrm{CD}^{+}$reconocieron las proteínas no estructurales NS3 y NS1.2A y la proteína E (de la envoltura). Todas las células de los donantes reconocieron NS3 o NS1.2A y en un donante que había recibido DEN-4 se encontraron por primera vez LT citotóxicos contra la proteína pre-M (precursora de la membrana) en cultivo policlonal. La respuesta de LT citotóxicos usando LMSP puede ser tanto seroespecífica como de reacción cruzada. En un donante la respuesta de LT citotóxicos específica para las proteínas E, NS1.2A, y NS3 fue restringida por HLA-B44. Para otros tres donantes los potenciales alelos de restricción de la proteína NS3 fueron B38, A24, o B62 y B35.

Estos estudios indican que la respuesta de los LT CD8 ${ }^{+}$citotóxicos humanos tras la inmunización con un serotipo de virus del dengue son diversas 


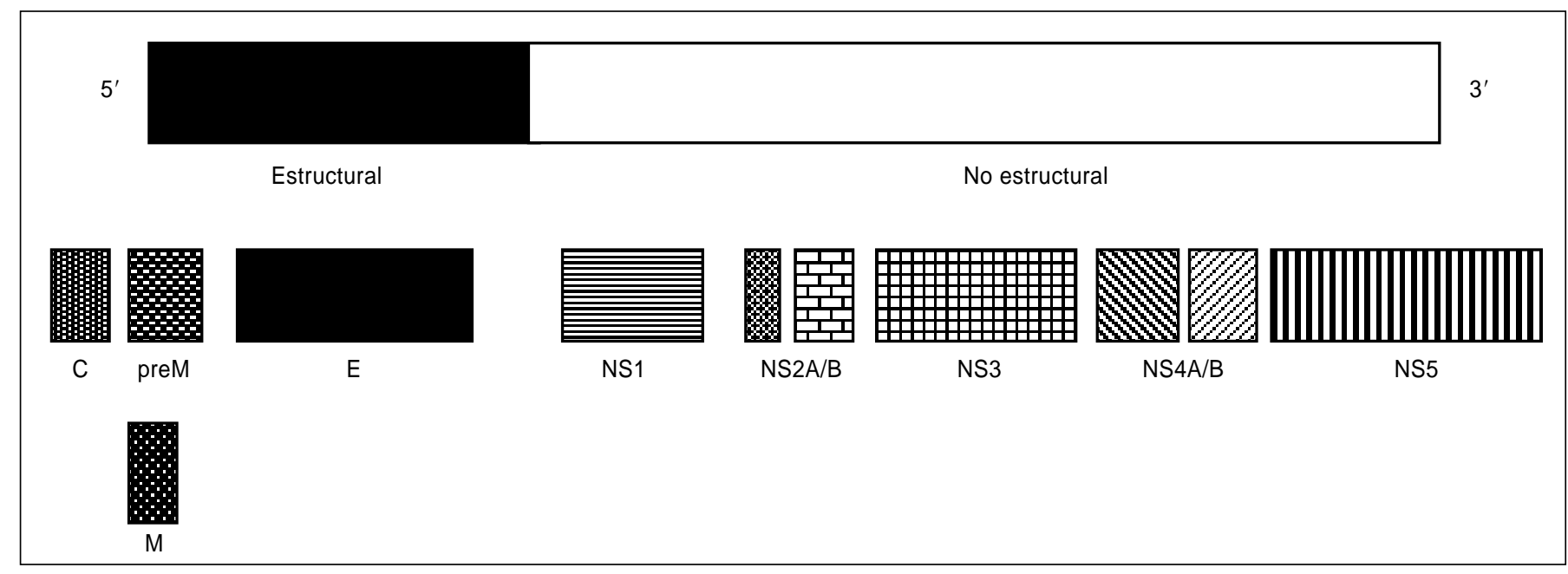

Proteínas estructurales: $\mathrm{C}$ - de la cápside; preM - premembrana; $\mathrm{M}$ - de la membrana, y E - de la envoltura. Proteínas no estructurales: NS1, NS2A/B, NS3, NS4A/B y NS5

y dirigidas contra varias proteínas. Aunque se ha sugerido que se consideren las proteínas $\mathrm{C}$ (de la cápside), preM, E, NS3 y NS1.2A para el diseño de subunidades de vacunas contra el dengue, habría que confirmar la presencia de otros inmunógenos igualmente importantes.

Los avances en las técnicas de biología molecular han permitido caracterizar mejor el genoma del virus del dengue y definir regiones antigénicas en proteínas estructurales $(C$, preM y E) y no estructurales (por ejemplo: NS3 y NS1.2A) (figuras 1 y 2). En el ser humano, la respuesta inmunitaria contra el virus del dengue es variada y está dirigida frente a diversos epitopos de las proteínas víricas. Estos epitopos, específicos para cada serotipo, pueden utilizarse para el diseño y creación de una vacuna polivalente que proteja contra los cuatro serotipos y garantice su calidad (13).

La proteína E es el componente más abundante de la envoltura del virión y en ella residen las propiedades biológicas más importantes del virus, como la unión al receptor celular o los epitopos que definen el serotipo y el tropismo celular. Los anticuerpos dirigidos contra la proteína E son los primeros en ser detectados en la infección por virus del dengue y los antígenos de esta proteína son los responsables de la respuesta inmunitaria de más larga duración. Al igual que la proteína E, las proteínas $\mathrm{C}$ y $\mathrm{M}$ han sido probadas en la inmunización de ratones y son capaces de proporcionarles protección frente a la exposición a dosis letales de virus del dengue (14). Los anticuerpos neutralizantes dirigidos contra la proteína $\mathrm{E}$ pertenecen al isotipo $\operatorname{IgG} 2 \mathrm{a}$. Los anticuerpos no neutralizantes, llamados "facilitadores", pertenecen a otro isotipo aún no identificado.

FIGURA 2. A) Proceso de maduración de las proteínas estructurales del virus dengue dentro de la célula huésped. La proteína preM mantiene estable a la proteína $E$. B) Desarrollo de la partícula vírica completa, madura e infecciosa. La conformación final del virión extracelular contiene los epitopos antigénicos funcionales

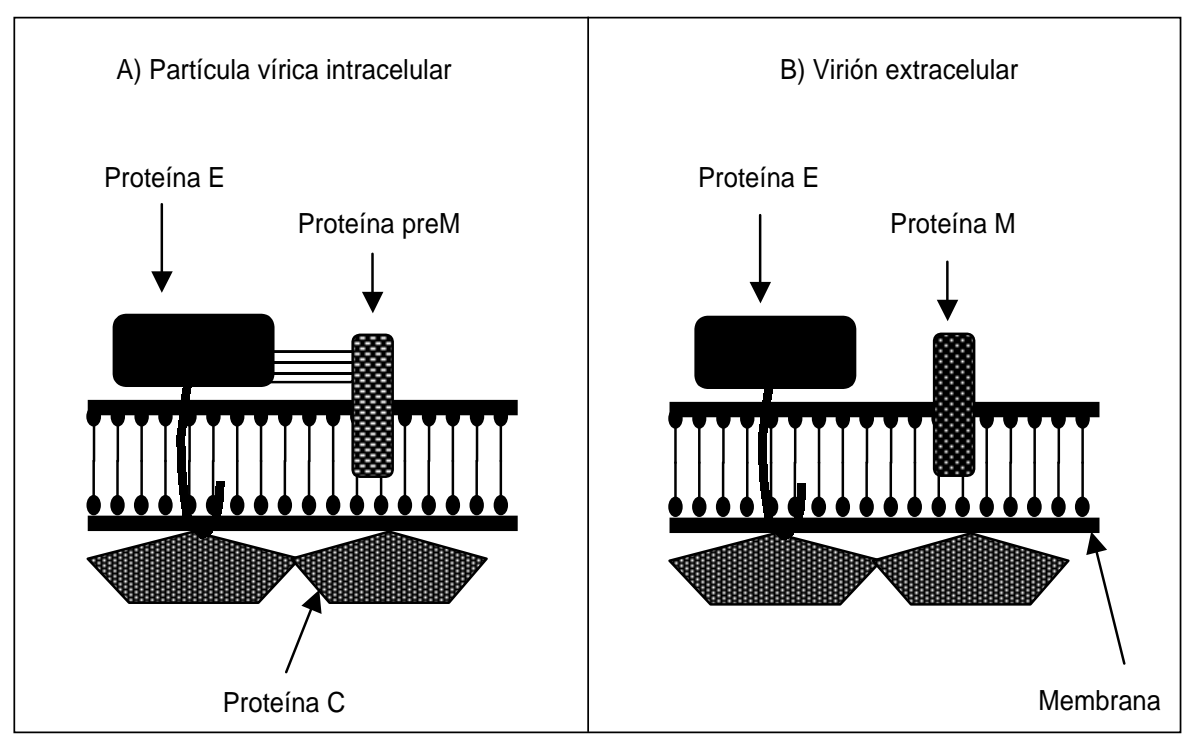


Las proteínas no estructurales, como NS1 y NS3, son capaces de inducir una respuesta inmunitaria protectora en modelos murinos y, como no están asociadas con partículas víricas libres, no existe el riesgo de que la infección sea potenciada por anticuerpos facilitadores. Esta característica las hace buenas candidatas para ser incluidas en el desarrollo de vacunas contra el dengue.

A continuación se hace un resumen de los avances conseguidos en el desarrollo de vacunas contra el dengue con virus atenuados, expresión de antígenos del virus del dengue en levaduras, vacunas con virus inactivados, vacunas recombinantes y vacunas de ADN.

\section{Vacunas con virus atenuados}

No es fácil producir una vacuna contra el virus del dengue con virus atenuados. Con la subatenuación, los virus pueden conservar su virulencia y con la sobreatenuación la respuesta inmunitaria es escasa en términos de seroconversión. Existen varios agentes inmunizantes candidatos con virus atenuados derivados de distintas cepas. En un estudio comparativo de la totalidad de las secuencias de nucleótidos de la cepa original West Pac 74 y de sus derivadas 45AZ5 PDK-O, virulenta, y 45AZ5 PDK-27, candidata a vacuna atenuada, Puri et al. (15) sugirieron que los cambios de nucleótidos observados, a pesar de alterar las propiedades biológicas del virus, podrían no ser importantes para la atenuación. En el caso de la cepa atenuada PDK-53, la comparación de la secuencia de aminoácidos con la cepa original DEN-2 16681 mostró cambios a lo largo del genoma. Estos cambios incluyeron $\mathrm{C}$ por $\mathrm{T}$ en la region 5' no traducida, Asp por Val en preM $^{29}$, Gly por Asp en NS1 ${ }^{53}$, Leu por Phe en NS2A ${ }^{181}$, Glu por Val en $\mathrm{NS3}^{250}$ y Gly por Ala en NS4A ${ }^{75}$, además de tres mutaciones silenciosas. En los ensayos in vitro se observó que la mutación Glu-Val en NS3 ${ }^{250}$ afecta a la capacidad replicativa del virus, que presenta placas más pequeñas y difusas, e incrementa su sensibilidad a la temperatura, pero estos factores no son

FIGURA 3. Virus quimérico VETG/DEN-4 (virus de la encefalitis transmitida por garrapatas/ dengue-4)

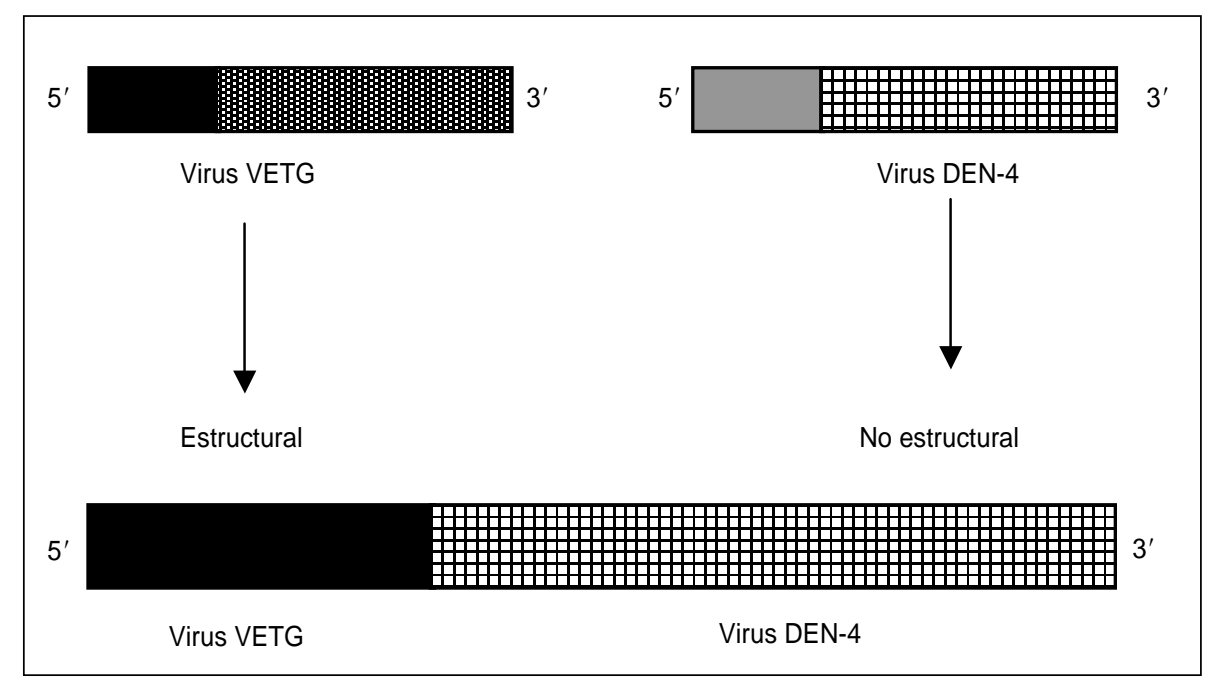

determinantes importantes para la atenuación del virus PDK-53 en ratones lactantes (16). Una vacuna con virus atenuados DEN-2 (cepa 16681 PDK 53), administrada por vía subcutánea a dosis de $10^{4}$ unidades formadoras de placa, demostró ser altamente inmunógena, ya que los 10 voluntarios receptores desarrollaron anticuerpos inmunizantes que persistieron dos años (17).

En otro estudio se evaluó en Macaca fascicularis la seguridad de la cepa atenuada PGMK 33 (DEN-3), derivada de la cepa 16562 DEN-3, para su uso como vacuna. No se observaron diferencias entre los efectos de los virus originales y los vacunales y se concluyó que ninguno de los dos es neurovirulento para estos monos (18).

Gagnon et al. (19) analizaron la respuesta de los $\mathrm{LT} \mathrm{CD}^{+}$de un donante que había recibido una vacuna experimental con virus DEN-4 vivos atenuados. Los resultados obtenidos indicaron que el paciente presentaba una respuesta de $\mathrm{LT} \mathrm{CD}^{+}{ }^{+}$con memoria dirigida frente a la proteína $\mathrm{C}$ y sugieren que esta respuesta es dominante no solo in vitro a nivel clonal, sino también en la respuesta de los cultivos policlonales. Como estudios anteriores han indicado que la respuesta de los
LT citotóxicos a la infección por virus del dengue parece estar dirigida particularmente contra las proteínas de la envoltura (E) y la proteína no estructural NS3, estos resultados fueron los primeros en indicar que la proteína de la cápside del virus del dengue también es diana de la respuesta inmunitaria antivírica de los LT.

Otra forma de atenuar la patogenia del virus del dengue consiste en la producción de quimeras, substituyendo secuencias que codifican algún factor virulento por los genes homólogos de un virus que no contenga en su genoma dichas secuencias. Así, por ejemplo, Pletnev y Men (20) produjeron una quimera sustituyendo los genes correspondientes del virus DEN-4 por los genes de las proteínas estructurales del virus de la encefalitis transmitida por garrapatas (VETG). La quimera VETG/DEN-4 (figura 3) se utilizó para crear clonas infecciosas de ADN con las que se inmunizaron ratones por vía intraperitoneal y se observó que no presentaron ninguna de las características de neurovirulencia asociadas con el VETG. Se han discutido ampliamente las implicaciones de estas observaciones para el desarrollo de una vacuna con virus vivos atenua- 
dos quiméricos que contengan genes del virus del dengue.

Chen et al. (21) construyeron una quimera DEN-3/DEN-4 que contiene los genes C-preM-E de DEN-3 y expresa especificidad antigénica contra el virus DEN-3 en ratones. Se produjeron dos cambios de aminoácidos Thr$\mathrm{Leu}^{435}$ y Glu-Lys ${ }^{406}$ en estos virus quiméricos, los cuales son análogos a los cambios que, en ratones, confieren neurovirulencia a DEN-4 y DEN-2, respectivamente. Además, la inoculación intracerebral en el ratón lactante reveló que la mutación Glu-Lys ${ }^{406}$ en la quimera es neurovirulenta, mientras que su contraparte silvestre de DEN-3 no lo es. También se ha empleado ADN complementario de longitud completa de DEN-4 para construir un virus quimérico viable DEN-1 o DEN-2 con antigenicidad específica que contenga las proteínas estructurales C-preM-E de DEN-1 o DEN-2, sustituyendo los genes correspondientes de DEN-4 (22). Esos virus quiméricos pueden ser usados para expresar antígenos específicos para cada serotipo en una vacuna tetravalente de virus quiméricos para uso en seres humanos.

\section{Expresión de antígenos de virus del dengue en levaduras}

Un abordaje distinto para expresar proteínas estructurales del virus del dengue con el fin de producir partículas pseudovíricas (PPV) consiste en utilizar los sistemas de expresión en levaduras. Las ventajas de estos sistemas están relacionadas con la facilidad de producción y la seguridad de los antígenos derivados de levaduras para su uso farmacológico o en vacunas. Fujita et al. (23) demostraron que la proteína E del virus de la encefalitis japonesa expresada en Saccharomyces cerevisiae es capaz de estimular la producción de anticuerpos neutralizantes. En el caso del virus del dengue, Sugrue et al. (24) utilizaron Pichia pastoris para generar PPV utilizando las proteínas estructurales (C-preM-E) de DEN-1. Los resultados de este trabajo demostraron que la expresión de las proteínas estructurales de DEN-1 en Pichia pastoris permitió generar PPV similares a los viriones y que las características bioquímicas y biológicas de las proteínas expresadas son similares a las de las proteínas nativas; además se demostró que estas PPV son inmunógenas y capaces de estimular la producción de anticuerpos neutralizantes.

\section{Vacunas con virus inactivados $\mathrm{y}$ vacunas recombinantes}

Putnak et al. $(25,26)$ exploraron la factibilidad de una vacuna purificada e inactivada producida en células Vero. A partir de una cepa candidata para vacuna de DEN-2 se cultivaron los virus, que fueron purificados e inactivados con formalina al 0,05\% a $22{ }^{\circ} \mathrm{C}$. En ensayos de inmunización en ratones y Macaca mulatta con dosis tan bajas como $0,15 \mathrm{mg}$ (con un refuerzo) y $0,25 \mathrm{mg}$ (con 2 refuerzos), respectivamente, se demostró que las vacunas purificadas e inactivadas son inmunógenas en ambos modelos animales. Se indujeron altos títulos de anticuerpos neutralizantes anti-DEN-2 y, en el caso de los ratones, estos quedaron protegidos completamente al ser expuestos al virus homólogo. En los monos vacunados se eliminó o redujo el período de viremia después de la exposición.

El empleo de subpartículas víricas recombinantes representa otra opción para el desarrollo de vacunas contra el dengue a base de virus vivos inactivados o atenuados. Para establecer la combinación más inmunógena, Fonseca et al. (27) crearon cuatro virus de la vacuna recombinantes que expresaban diferentes porciones del genoma del virus DEN-1 (C-preM-E-NS1NS2A-NS2B; preM-E; preM-E-NS1NS2A-NS2B, y NS1-NS2A). Los dos virus recombinantes productores de proteínas preM y E en ausencia de C indujeron la síntesis de formas extracelulares de E in vitro y cuando se inocularon a ratones indujeron la producción de anticuerpos neutralizantes e inhibidores de la hemaglutinación contra DEN-1. Los otros dos virus de la vacuna recombinantes no produjeron formas extracelulares de $\mathrm{E}$ ni indu- jeron respuesta inmunitaria específica. Estos resultados, que demuestran la importancia de la coexpresión de las proteínas preM y E para inducir la producción de anticuerpos neutralizantes e inihibidores de la hemaglutinación para su posible uso en una vacuna contra el virus del dengue, apoyan los estudios previos sobre el diseño de vacunas con flavivirus-virus de la vacuna.

Staropoli et al. (14) crearon un baculovirus recombinante que produce la proteína E del virus DEN-2. La proteína recombinante se purificó a partir del sobrenadante de los cultivos de células del insecto Spodoptera frugiperda infectadas con el baculovirus recombinante. Los ratones inoculados con la proteína E purificada mezclada con hidróxido de aluminio como adyuvante mostraron una respuesta inmunitaria humoral IgM e IgG (IgG1, IgG2a e IgG2b), con anticuerpos neutralizantes, similar a la obtenida tras la inmunización con virus DEN-2 purificados e inactivados. Los ratones que recibieron la proteína purificada recombinante presentaron buena protección contra 200 dosis letales medias de virus DEN-2. Esta estrategia parece prometedora para la producción de partículas proteínicas inmunógenas, especialmente proteínas de los cuatro serotipos de virus del dengue, y el desarrollo de una nueva generación de vacunas.

Srivastava et al. (28) expresaron en Escherichia coli un fragmento de gen que codifica 204 aminoácidos de la región C-terminal de la proteína E y 65 aminoácidos de la porción $\mathrm{N}$-terminal de la proteína no estructural NS1 de DEN-2, como proteína de fusión con proteína A estafilocócica. La proteína recombinante de fusión se purificó y se analizó para evaluar su antigenicidad e inmunogenicidad, así como su capacidad para proteger a los ratones contra la exposición letal a virus DEN2. La proteína reaccionó con anticuerpos monoclonales y policlonales antiDEN-2. Los ratones inmunizados produjeron anticuerpos anti-DEN-2 que se demostraron mediante pruebas de inhibición de la hemaglutinación y neutralización, y fueron protegidos 
contra la exposición letal a virus DEN2 inoculado por vía intracraneal.

Es importante conocer el tipo de subclases de inmunoglobulinas que se generan después de la inmunización con vacunas contra el virus del dengue, ya que la inmunización de ratones con virus vivos origina una respuesta predominantemente de IgG2a, que puede ser la más eficaz para resistir exposiciones futuras. Smucny et al. (29) midieron las respuestas específicas de las diferentes subclases de IgG en ratones $\mathrm{BALB} / \mathrm{c}$ inmunizados con virus vivos o con una proteína $\mathrm{E}$ recombinante parcialmente purificada de DEN-2. Las respuestas de las distintas subclases de IgG tras la inmunización con virus vivos presentaron el siguiente orden de magnitud IgG2a > IgG1 > IgG2b > IgG3, y tras la inmunización con proteína E recombinante, IgG1 > IgG2a > IgG2b > IgG3. Los niveles de casi todas las subclases (excepto IgG1) y los niveles de anticuerpos neutralizantes fueron mayores con los virus vivos que con la proteína $\mathrm{E}$ recombinante. Después de purificar las cuatro subclases de IgG por cromatografía, la fracción IgG2a mostró la mayor actividad neutralizante. Los resultados de este trabajo indican que la inmunización con virus vivos y con la proteína E recombinante induce un patrón distinto de subclases de IgG, son compatibles con estudios realizados con otros virus y proteínas víricas y podrían tener implicaciones para el desarrollo de nuevas vacunas eficaces contra el dengue.

El gen que codifica la glucoproteína E de la envoltura del virus DEN-2 se clonó en un baculovirus (virus de la poliedrosis nuclear de Autographa californica). El virus recombinante contenía el gen entero de la proteína E precedido por 38 nucleótidos de la región C-terminal de preM y seguido por los 83 primeros nucleótidos de la proteína NS1. Cuando se expresó en células de Spodoptera frugiperda (Sf 9), se obtuvo aproximadamente $1 \mathrm{mg}$ de antígeno $\mathrm{E}$ recombinante por $10^{9}$ células. Este antígeno fue reconocido por anticuerpos policlonales anti-DEN-2 y por anticuerpos monoclonales neutralizantes específicos frente a DEN-2. A pesar de haberse producido títulos $<10$ de anticuerpos neutralizantes de reducción de placa contra virus DEN-2, los ratones $\mathrm{BALB} / \mathrm{c}$ vacunados se inmunizaron parcialmente y se redujo su morbilidad y mortalidad tras la exposición intracraneana a virus DEN-2 virulentos (30).

Por último, se han utilizado virus de la vacuna recombinantes que contienen proteínas del virus del dengue para evaluar la respuesta de los LT $\mathrm{CD}^{+}$citotóxicos en donantes inmunizados con prototipos de vacunas. Green et al. (31), demostraron que las clonas de LT CD4 ${ }^{+}$citotóxicos de sangre periférica de un donante inmunizado con una vacuna experimental contra el virus DEN-1 reconocen, específicamente o en reacción cruzada con DEN-3, epitopos de las proteínas NS1 y NS2a. Además, los resultados del análisis de la restricción por el complejo mayor de histocompatibilidad mostraron que las clonas específicas están restringidas por HLA-DR1 y las de reacción cruzada por HLA-DPw3. Estos resultados indican que las proteínas NS1 y NS2a, al igual que las proteínas C, E y NS3, contienen epitopos que son reconocidos por LT CD4 ${ }^{+}$ específicos contra el virus del dengue $\mathrm{y}$, por lo tanto, deben ser consideradas en el diseño de una vacuna.

\section{Vacunas de ADN}

Las vacunas de ADN representan una técnica novedosa que expresa antígenos in vivo para estimular la respuesta inmunitaria humoral y celular. Estas vacunas promisorias se han probado en modelos experimentales, principalmente en animales de laboratorio, desde 1993. Esas pruebas han incluido la inmunización contra diversas enfermedades producidas por virus, bacterias y protozoos. En el caso del virus del dengue, Kochel et al. (32) evaluaron la respuesta inmunitaria humoral contra el virus DEN-2 en ratones inmunizados con plásmidos que contienen los genes de preM y de $92 \%$ de la proteína E de DEN-2 (cepa de Nueva Guinea C). Los resultados mostraron que los ratones inmunizados produjeron anticuerpos capaces de neutralizar el virus in vitro. En un segundo estudio, Porter et al. (33) evaluaron la capacidad protectora de esta vacuna de ADN utilizando un modelo de exposición letal intracerebral en ratones. Además, examinaron el efecto inmunoestimulante de los motivos CpG presentes en el plásmido pUC19 sobre la respuesta humoral. Los resultados revelaron que los motivos CpG incrementan significativamente la respuesta de anticuerpos a pequeñas dosis $(3,1 \mu \mathrm{g})$ de la vacuna y que $60 \%$ de los ratones coinmunizados con la vacuna y con pUC19 sobrevivieron después de la exposición. Estos estudios ilustran que la inmunización con ADN es un abordaje viable para el desarrollo de una vacuna contra el dengue y que los motivos inmunoestimulantes CpG podrían servir para reducir la dosis mínima requerida de vacuna necesaria para producir una respuesta de anticuerpos.

\section{CONCLUSIONES}

Sobre la base de los avances actuales en el conocimiento de la patogenia de la infección/enfermedad, deben definirse prioridades y trazarse estrategias para acelerar el desarrollo de agentes inmunizantes seguros, eficaces, estables y accesibles que prevengan la neurovirulencia, el síndrome de choque y las manifestaciones hemorrágicas del dengue y otras flavivirosis. En este sentido, las vacunas deben inducir una respuesta inmunitaria que tenga las siguientes características:

- producir anticuerpos citolíticos o no líticos bloqueantes de la replicación del virus,

- activar LT específicos,

- estimular la secreción de citoquinas para suprimir la replicación del virus,

- neutralizar y eliminar los virus extracelulares y las toxinas,

- ayudar a la diferenciación, expansión y maduración de los LT citotóxicos y de los linfocitos $\mathrm{B}$,

- englobar, procesar, fragmentar y presentar péptidos a los receptores respectivos del complejo mayor 
de histocompatibilidad (MCH I y MCH II), y

- no inducir LT citotóxicos ni citoquinas de estas células que actúen a favor de la infección por virus del dengue.

La diseminación de los cuatro serotipos del virus del dengue ha aumentado la incidencia notificada de $\mathrm{DH}$. Con 2,5 mil millones de habitantes en riesgo, deben acelerarse los esfuerzos para desarrollar una vacuna segura y eficaz contra el dengue. Pueden aprenderse las lecciones que sobre patogenia nos dan los estudios clásicos en el campo y trasladarlos al contexto actual del conocimiento de la epidemiología molecular del virus del dengue. El diseño de vacunas con subunidades o con virus completos llama particularmente la atención sobre el fenómeno de la potenciación dependiente de anticuerpos y, en general, de la inmunopotenciación de la enfermedad. Deben hacerse mayores esfuerzos para comprender las bases de la patogenia del $\mathrm{DH}$, a fin de diseminar el conocimiento sobre la protección contra la infección por el virus del dengue y sobre la recuperación de la enfermedad producida por el mismo (34).

Para obtener la vacuna contra el dengue es necesario identificar antígenos que produzcan inmunidad protectora para toda la vida y contra los cuatro serotipos del virus. Deben con- siderarse las diferentes estrategias, desde la atenuación convencional del virus hasta las vacunas de segunda generación (inmunización con proteínas) y tercera generación (inmunización con $\mathrm{ADN}$ ), las proteínas estructurales de envoltura y de membrana y las proteínas no estructurales NS1 y NS3. A pesar de los avances realizados, aún se necesita información sobre la pureza, estabilidad, seguridad, presentación, vía de administración y proceso de producción, control y garantía de la calidad, antes de disponer de un producto final eficaz durante la primera década de este siglo (35).

Las estrategias actuales para la inmunización contra el dengue favorecen el uso de vacunas que contengan antígenos inmunodominantes contra los cuatro serotipos. El reto consiste en usar proteínas estructurales, no estructurales o ambas, expresadas mediante la tecnología de proteínas recombinantes.

Se han probado en voluntarios posibles vacunas contra los cuatro serotipos que han sido inmunógenas y seguras. Aunque las vacunas con virus atenuados son prometedoras, son necesarios nuevos estudios sobre su eficacia y seguridad. Lamentablemente, todavía no se han obtenido resultados satisfactorios en el ser humano.

Las vacunas con $A D N$ pueden inducir intensas respuestas humorales y celulares sin adyuvante adicional. Estu- dios recientes indican que los dinucleótidos no metilados CpG (motivos) incorporados a las vacunas de ADN estimulan la respuesta inmunitaria y ejercen una actividad adyuvante endógena esencial. Estos motivos CpG pueden agregarse deliberadamente al ADN junto con el antígeno que se quiere expresar para potenciar la respuesta inmunitaria Th1 $(36,37)$.

Es necesario fomentar la vigilancia epidemiológica de la enfermedad, incluido el establecimiento de una red de laboratorios de diagnóstico y centros de referencia, a fin de caracterizar la circulación del virus. Durante las epidemias de dengue pueden aparecer mutantes antigénicos. Aunque estos mutantes no reflejen un aumento de la virulencia, podría ser útil conocerlos para seleccionar las cepas más adecuadas para la elaboración de la mejor vacuna en la Región. La necesidad de desarrollar vacunas eficaces contra el dengue tiene especial importancia si se toma en cuenta la magnitud del problema de la circulación de los cuatro serotipos en el mundo. Una vacuna eficaz contra el dengue contribuirá a su prevención y control y la relación costo-beneficio será positiva. El hecho de que el dengue endémico afecte a niños de corta edad subraya la necesidad de inmunizarlos, aprovechando la oportunidad que ofrece el Programa Ampliado de Inmunización.

\section{REFERENCIAS}

1. Henchal EA, Putnak JR. The dengue viruses. Clin Microbiol Rev 1990;3:376-396.

2. Gubler DJ. Dengue and dengue hemorrhagic fever. Clin Microbiol Rev 1998;11:480-496.

3. López Antuñano FJ. Epidemiology and control of malaria and other arthropod borne diseases. Mem Inst Oswaldo Cruz 1992;87(Supl 3):105-114.

4. Shope RE. Concepts of control of Japanese encephalitis and dengue. Southeast Asian J Trop Med Public Health 1997;28(Supl 2):131-134.

5. Lambert PH. Les vaccins de l'an 2000. Bull Soc Pathol Exot 1997;90:238.

6. Hammon WM. Dengue hemorrhagic fever. Do we know its cause? Am J Trop Med Hyg 1973; 22:82-91.

7. Valdés L, Guzmán MG, Kouri G, Delgado J, Carbonell I, Cabrera MV, et al. La epidemiología del dengue y del dengue hemorrágico en Santiago de Cuba, 1997. Rev Panam Salud Pública 1999;6:16-25.

8. Gubler DJ. Resurgent vector-borne diseases as a global health problem. Emerg Infect Dis 1998;4:442-450.

9. Ellis RW. The new generation of recombinant viral subunit vaccines. Curr Opin Biotechnol 1996;7:646-652.

10. Halstead SB, O'Rourke EJ. Dengue viruses and mononuclear phagocytes. I. Infection enhancement by non-neutralizing antibody. J Exp Med 1977;146:201-217.

11. Kurane I, Innis BL, Hoke CH Jr, Eckels KH, Meager A, Janus J, et al. T cell activation in vivo by dengue virus infection. J Clin Lab Immunol 1995;46:35-40.

12. Halstead SB. Pathogenesis of dengue: challenges to molecular biology. Science 1988; 239(4839):476-81.
13. Mathew A, Kurane I, Rothman AL, Zeng LL, Brinton MA, Ennis FA. Dominant recognition by human CD8+ cytotoxic T lymphocytes of dengue virus nonstructural proteins NS3 and NS1.2a. J Clin Invest 1996;98:1684-1691.

14. Staropoli I, Frenkiel MP, Megret F, Deubel V. Affinity-purified dengue-2 virus envelope glycoprotein induces neutralizing antibodies and protective immunity in mice. Vaccine 1997;15:1946-1954.

15. Puri B, Nelson WM, Henchal EA, Hoke $\mathrm{CH}$, Eckels KH, Dubois DR, et al. Molecular analysis of dengue virus attenuation after serial passage in primary dog kidney cells. J Gen Virol 1997;78:2287-2291.

16. Kinney RM, Butrapet S, Chang GJ, Tsuchiya KR, Roehrig JT, Bhamarapravati N, et al. Construction of infectious cDNA clones for dengue 2 virus: strain 16681 and its attenu- 
ated vaccine derivative, strain PDK-53. Virology 1997;230:300-308.

17. Vaughn DW, Hoke CH Jr, Yoksan S, LaChance R, Innis BL, Rice RM, et al. Testing of a dengue 2 live-attenuated vaccine (strain 16681 PDK 53) in ten American volunteers. Vaccine 1996;14:329-336.

18. Angsubhakorn S, Yoksan S, Pradermwong A, Nitatpattana N, Sahaphong S, Bhamarapravati N. Dengue-3 (16562) PGMK 33 vaccine: neurovirulence, viremia and immune responses in Macaca fascicularis. Southeast Asian J Trop Med Public Health 1994;25:554- 559.

19. Gagnon SJ, Zeng W, Kurane I, Ennis FA. Identification of two epitopes on the dengue 4 virus capsid protein recognized by a serotypespecific and a panel of serotype-cross-reactive human CD4+ cytotoxic T-lymphocyte clones. J Virol 1996;70:141-147.

20. Pletnev AG, Men R. Attenuation of the Langat tick-borne flavivirus by chimerization with mosquito-borne flavivirus dengue type 4 . Proc Natl Acad Sci U S A 1998;95:1746-1751.

21. Chen W, Kawano H, Men R, Clark D, Lai CJ. Construction of intertypic chimeric dengue viruses exhibiting type 3 antigenicity and neurovirulence for mice. J Virol 1995;69:5186-5190.

22. Bray M, Men R, Lai CJ. Monkeys immunized with intertypic chimeric dengue viruses are protected against wild-type virus challenge. J Virol 1996;70:4162-4166.

23. Fujita H, Sumiyoshi H, Mori C, Manabe S, Takagi M, Yoshida I, et al. Studies in the development of Japanese encephalitis vaccine: expression of virus envelope glycoprotein V3
(E) gene in yeast. Bull World Health Organ 1987;65:303-308.

24. Sugrue RJ, Fu J, Howe J, Chan Y-C. Expression of the dengue virus structural proteins in Pichia pastoris leads to the generation of virus-like particles. J General Virol 1997;78:1861-1866.

25. Putnak R, Barvir DA, Burrous JM, Dubois DR, D'Andrea VM, Hoke $\mathrm{CH}$, et al. Development of a purified, inactivated, dengue-2 virus vaccine prototype in Vero cells: immunogenicity and protection in mice and rhesus monkeys. J Infect Dis 1996;174:1176-1184.

26. Putnak R, Cassidy K, Conforti N, Lee R, Sollazzo D, Truong T, et al. Immunogenic and protective response in mice immunized with a purified, inactivated, dengue- 2 virus vaccine prototype made in fetal rhesus lung cells. Am J Trop Med Hyg 1996;55:504-510.

27. Fonseca BA, Pincus S, Shope RE, Paoletti E, Mason PW. Recombinant vaccinia viruses coexpressing dengue-1 glycoproteins prM and $\mathrm{E}$ induce neutralizing antibodies in mice. Vaccine 1994;12:279-285.

28. Srivastava AK, Putnak JR, Warren RL, Hoke $\mathrm{CH}$ Jr. Mice immunized with a dengue type 2 virus E and NS1 fusion protein made in Escherichia coli are protected against lethal dengue virus infection. Vaccine 1995;13:12511258.

29. Smucny JJ, Kelly EP, MaCarthy PO, King AD. Murine immunoglobulin $G$ subclass responses following immunization with live dengue virus or a recombinant dengue envelope protein. Am J Trop Med Hyg 1995;53: 432-437.
30. Feighny R, Burrous J, Putnak R. Dengue type2 virus envelope protein made using recombinant baculovirus protects mice against virus challenge. Am J Trop Med Hyg 1994;50:322328.

31. Green S, Kurane I, Pincus S, Paoletti E, Ennis FA. Recognition of dengue virus NS1-NS2a proteins by human CD4+ cytotoxic T lymphocyte clones. Virology 1997;234:383-386.

32. Kochel T, Wu S-J, Raviprakash K, Hobart P, Hoffman S, Porter K, et al. Inoculation of plasmids expressing the dengue-2 envelope gene elicit neutralizing antibodies in mice. Vaccine 1997;15:547-552.

33. Porter KR, Kochel TJ, Wu SJ, Raviprakash K, Phillips I, Hayes CG. Protective efficacy of a dengue 2 DNA vaccine in mice and the effect of CpG immuno-stimulatory motifs on antibody responses. Arch Virol 1998;143:997-1003.

34. Cardosa MJ. Dengue vaccine design: issues and challenges. Br Med Bull 1998;54:395-405.

35. Guzmán MG. Avances en el desarrollo de una vacuna contra dengue. Acta Cient Venez 1998;49(Supl 1):38-45.

36. Krieg AM, Yi AK, Schorr J, Davis HL. The role of CPG dinucleotides in DNA vaccines. Trend Microbiol 1998;6:23-27.

37. Krieg AM. CpG DNA: a novel immunomodulator. Trend Microbiol 1999;7;64-65.

Manuscrito recibido el 2 de noviembre de 1999 y aceptado para publicación, tras revisión, el 3 de abril de 2000.
ABSTRACT

\section{Development of immunizing agents against dengue}

The four serotypes of dengue flaviviruses are transmitted mainly by the Aedes aegypti mosquito, and some epidemics have been attributed to Ae. albopictus, Ae. polynesiensis, and various species of the Ae. scutellaris complex. The risk factors involved in dengue mortality and morbidity are related to the human host (genetic characteristics of infected persons; lifestyles, immune status, and health conditions of people; basic sanitation of dwellings; and water supply) and to the virus (genetic variability between and among serotypes, different pathogenicities, and geographic distribution). Notwithstanding the lack of knowledge of the immunopathobiology of dengue fever, important advances have been made in terms of a protective immune response, using attenuated dengue viruses or antigens produced by means of recombinant technologies. Efforts have been made since the 1940s to develop dengue vaccines. Immunity acquired from natural infection is specific for each serotype, and as many as three different serotype infections have been reported in one individual. For this reason, a tetravalent vaccine may likely be needed. Candidate vaccines against the four serotypes have been tested in volunteers and have proven to be immunogenic and safe. Although attenuated live virus vaccines are promising, more study is needed regarding their effectiveness and safety. Currently, several studies are ongoing to develop dengue vaccines using antigens from structural proteins (particularly E glycoprotein) and nonstructural proteins, with recombinant DNA technology and other biomolecular technologies. With the same goal, various expression vectors are being used, including Escherichia coli, baculovirus, vaccinia virus, and yellow fever virus. Unfortunately, no satisfactory results have been obtained in humans. The need for effective dengue vaccines is great, given the serious worldwide problem of the transmission of the four serotypes. Effective immunization against dengue would contribute to its prevention, with a positive costbenefit relationship. Endemic dengue affects young children, and they should be immunized through the Expanded Program on Immunization. 